\title{
Processing of Satellite Imagery with Satellite "Terra" to Decipher the Oil-Bearing Geological Structures of South of Western Siberia
}

\author{
Andrei Yu. Belonosov, \\ Anton E. Kudriavtcev and Dmitrii V. Borisov* \\ West Siberian Branch of Trofimuk Institute \\ of Petroleum-Gas Geology and Geophysics SB RAS \\ 74 Taymyrskaya Str., Tyumen, 625000, Russia
}

Received 15.12.2016, received in revised form 16.05.2017, accepted 14.06.2017

The use of remote sensing data based on specialized algorithms for processing of thermal images of Earth's surface in conjunction with the geological and geophysical data simplifies the allocation of oil-bearing geological structures.

Keywords: remote sensing data, thermal satellite imagery, earth surface temperature, convective thermal flux, moisture evaporation rate, thermal inertia, digital elevation model, oil-bearing geological structures.

Citation: Belonosov A.Yu., Kudriavtcev A.E., Borisov D.V. Processing of satellite imagery with satellite "terra" to decipher the oil-bearing geological structures of south of western siberia, J. Sib. Fed. Univ. Eng. technol., 2017, 10(6), 758-763. DOI: 10.17516/1999-494X-2017-10-6-758-763.

(C) Siberian Federal University. All rights reserved

* Corresponding author E-mail address: belonosov74313@mail.ru, kudryavtsevae85@mail.ru 


\title{
Обработка космических снимков со спутника «Terra» для дешифрирования нефтеперспективных геоструктур юга Западной Сибири
}

\author{
А.Ю. Белоносов, \\ А.Е. Кудрявцев, Д.В. Борисов \\ Западно-Сибирский филиал Института \\ нефтегазовой геологии и геофизики \\ им. А.А. Трофимука СО РАН \\ Россия, 625000, Тюмень, ул. Таймырская, 74
}

Использование материалов дистанционного зондирования Земли из космоса, основанное на специиализированном алгоритме обработки тепловых изображений земной поверхности, совместно с геолого-геофизическими данными упрощает выделение нефтеперспективных геоструктур.

Ключевые слова: материаль дистанционного зондирования Земли из космоса, тепловая космическая съемка, температура земной поверхности, конвективный тепловой поток, скорость испарения влаги, тепловая инериия, ичифровая модель рельефа, нефтеперспективные геоструктуры.

\section{Introduction}

Multivariate regression analysis of the hydrocarbons deposits (HD) placement and Earth remote sensing data (ERSD) showed that the most of oil and gas fields are located near the thermal linear and thermal annular zones [1-6].

Most specific method in oil-geostructures predicting for remote sensing data is thermal satellite imagery - TSI [7-11].

\section{Problem formulation}

The classical method of the thermal flux (TF) calculation from the Earth's depths is based on the theory of conductive thermal conduction. At the same time, there is another physical process of thermal transfer in the earth's crust - convective thermal and mass transfer component [4].

Convective thermal flux (CTF) depends on the lifting rate of deep fluid. The temperature of the earth's surface (TES) will be higher in areas where a high rate of fluid lifting is observed in the Earth's crust. Areas with conductive thermal transfer nature may be taken as a background areas. Positive temperature contrasts are recorded above places with high convective thermal and mass transfer on the earth's surface (ES).

High values of CTF in the earth's crust appeared the physical basis for the development of TSI processing algorithm including a mathematical model of the annual and diurnal variations of TES.

\section{Input data}

To solve the problem Terra (MODIS) satellite data had been used on the territory of the south of Western Siberia, where oil and gas is not yet open (Kurgan region). 
Digital images in the near and far infrared bands obtained with the MODIS spectroradiometer were selected on the Moscow station of receiving satellite data. 400 scenes were analyzed, only 15 scenes were taken for processing.

In the territorial funds of geological information data of geological and geophysical content were collected and systematized.

\section{Processing of data}

Thermodynamic TES was determined using the radiation temperature and radiation coefficients.

In the first step calibration of the radiation intensity was carried out to various image brightnesses using calibration functions.

In the second step radiometric correction was carried. Radiation intensity values $\mathrm{L}$ are converted into brightness temperature $T_{R}$ according to Planck inverse function.

In the third step atmospheric correction was conducted which is based on the assumption of a linear relationship between thermodynamic temperature $T_{t d}$ and brightness temperatures in the 4 th and 5th spectral bands $\left(T_{R 4}\right.$ and $\left.T_{R 5}\right)$.

An important element in the calculation was the aprioristic knowledge of the Earth surface emissivity values $\varepsilon_{4}$ и $\varepsilon_{5}$.

Software products of MODIS site were used for thermal processing of images.

After the mentioned above steps important operations for obtaining of thermal images were the binding to a cartographic projection and accounting geometric distortion MRSE from space.

Having processed thermal image, the next step of the specialized processing was determination of the ES physical characteristics that affect TES.

To determine the remote ES coming from the subsoil, it is necessary from the TSI initial results to eliminate the effects of other factors: the impact of the long-wave and short-wave solar radiation, ES heat consumption on turbulent heat exchange with the atmosphere, the heat consumptions on evaporation and heat costs due to diurnal and annual heat rhythms.

The main purpose of the specialized processing of thermal satellite data is the calculation of the ES physical characteristics: the flux density of the total solar radiation, albedo, emissivity, thermal inertia (TI), CTF of subsoil, soil moisture, the geometry of the Earth's surface, soil structure, meteorological conditions, the concentration of optically active gases in the atmosphere $\left(\mathrm{CO}_{2}, \mathrm{SO}_{2}\right)$ and time. They were used for zoning, determining the parameters of geological bodies occurrence and the parameters of the processes occurring in the Earth's crust.

For mapping of CTF, TI and the rate of moisture evaporation (RE) a standard set of meteorological data obtained at meteorological stations in the south of the Tyumen region were used (temperature, moisture and air pressure at a height of 2 meters, the wind speed at a height of 10 meters, cloudy). The total solar radiation was calculated using the cloudy values by the Berlyand formula.

The calculation algorithm CTF, TI and RE based on the mathematical model of the TES diurnal variation.

To solve the inverse problem, i.e., to determine three main parameters according to TSE - CTF, TI and RE, three surveys was done at different times of the day.

To account for the impact of landforms absorbing solar radiation the algorithm provides the use of a digital elevation model (DEM). 
The inverse problem was solved through a defined criterion of appropriate measured and ideal (located in the "library") TES. Using the method of least squares CTF, TI and RE required values were defined.

Based on the mean square error CTF measured values in excess of $10 \mathrm{~W} / \mathrm{m}^{2}$ were considered as reliable. Deviations in excess of $30 \mathrm{~W} / \mathrm{m}^{2}$ for a single pixel was taken for the abnormality.

Through TES regular monitoring in the Kurgan region and restoring MRES from space ES quantitative characteristics time series were obtained. Further the mathematical analysis of temporal variations of the quantitative characteristics was carried out.

It was implemented two approaches to the analysis of time series: differential - boils down to the subtraction of the two maps of recovered surface characteristics obtained at different times; statistical based on the calculation of statistical parameters of studied quantitative characteristics, restored by MRES.

Then the following procedures of mathematical analysis of images made through software package ERDAS IMAGINE were applied: color coding, factor analysis, reference-free classification, the reference classification, multivariate regression analysis.

Processing of the image prepared set was performed to decipher the thermally active linear and annular zones.

For zoning digital mosaics composed of different characteristics were created.

On the thermal images obtained of TES, RE, TI, CTF and images of lineaments, annular structures, DEM and other indications similar areas, the underlying structures and the bodies for geological recognition were identified.

To decrypt promising oil-geostructures the data classification procedure was applied. Three methods of classification of digital data were used: the construction of the color composite images, standardless classification with k-means method and the reference classification with maximum likelihood method.

In the reference classification feature space includes about 20 features. As a training sample oil, oil-and-condensate and gas-condensate fields listed in the "Russian Natural Resources" GIS were used. 37 features were selected for analysis.

\section{Discussion of research results}

Thermal imaging analysis was carried out to identify the possible relation of thermal annular and linear zones of different orders with oil-gas deposits of the south of Western Siberia.

The analysis results of thermal images and placement of hydrocarbon deposits in the south of Western Siberia has allowed to formulate interpretive criteria: the presence of a thermally active linear zones; the presence of thermal annular zones of the first and second order, third-order annular complicated areas; the presence of lower values CTF areas adjoining the thermally active areas of different types and order.

In the south of Western Siberia (Kurgan region) a single most promising area in search of hydrocarbons was recorded. This area is located in the central part of Zverinogolovskoye-Vargashi paleovalley of pre-Jurassic basement where the Upper Paleozoic marine carbonate sediments are developed. 


\section{Conclusions}

1. Quantitative characteristics were used to isolate the oil-bearing geological structures in the south of Western Siberia on the thermal satellite images: ES emissivity, ES albedo, TI, RI, CTF, DEM and their various composites.

2. TSI was used to predict the oil-squares method. ES thermal zoning of south of Western Siberia was investigated.

3. Interpretive criteria are set for the detection of hydrocarbon deposits on the thermal satellite images.

4. The most promising area to search for hydrocarbon deposits is a central part of Zverinogolovskoye-Vargashi paleovalley of pre-Jurassic basement (the eastern part of the Kurgan region).

5. TSI is a promising, low-cost and rapid method to predict the hydrocarbon accumulations in the vast, little-known and remote areas.

\section{References}

[1] Белоносов А.Ю. Комплексирование результатов тепловизорной аэросъемки и приповерхностной геотермической съемки на нефтяных месторождениях Западной Сибири, Mатериалы IV Республиканской конференции «Прямые методы поисков залежей нефти и газа», ИГГГИ, Львов, 1990, 41-44 [Belonosov A.Yu. Complexing of the results of thermal aerial survey and near-surface geothermal survey on the oil fields of Western Siberia, Proceedings of the IV Republican conference "Direct methods of oil and gas exploration”, IGGCM, Lviv (in Russian)]

[2] Горный В.И., Степанов И.В. Комплексирование тепловой многоспектральной и аэромагнитной съемок при решении прогнозно-поисковых задач, Разведка и охрана недр, 2001, 9, 39-43 [Gornyi V.I., Stepanov I.V. Complexing of thermal multispectral and aeromagnetic surveys for solving forecasting and search problems. Exploration and conservation of mineral resources, 2001, 9, 39-43 (in Russian)]

[3] Запивалов Н.П., Белоносов А.Ю. Локальный прогноз нефтегазоносности с помощью тепловых методов, Геолого-геохимические условия формирования нефтегазоносныхотложений Западной Сибири. Труды ЗапСиБНИГНИ, Тюмень, 1991, 123-126 [Zapivalov N.P., Belononsov A.Yu. Local forecast oil and gas potential using thermal methods. Proceedings of West-SibSRGPI "Geological and geochemical conditions of oil and gas deposits formation in Western Siberia", Tyumen, 1991, 123-126 (in Russian)]

[4] Горный В.И., Шилин Б.В., Ясинский Г.И. Тепловая аэрокосмическая съемка. М.: Недра, 1993, 128 c. [Gornyi V.I., Shilin B.V., Iasinskii G.I. Thermal aerospace survey. Moscow: Nedra, 1993, 128 p. (in Russian)]

[5] Горный В.И., Крицук С.Г. Прогноз нефтеперспективных площадей в республике Чувашия на основе визуального и инструментального анализа цифровых космических материалов, Тезисы докладов Второй международной конференщии «Перспективы развития и освоения топливно-энергетической базы Северо-Западного экономического района Российской Федераиии», Санкт-Петербург, 2000, 41-42 [Gornyi V.I., Kricjuk S.G. Forecast of oil-bearing areas in Chuvashia republic based on visual and instrumental analysis of digital satellite data, Abstracts of the Second International Conference "Prospects of development and the development of fuel and 
energy base of the Northwestern economic region of the Russian Federation”. Saint-Petersburg, 2000, 41-42 (in Russian)]

[6] Белоносов А.Ю., Туренко С.К. Интерпретация спутниковых данных конвективного теплового потока при прогнозировании залежей углеводородов в Курганской области, Известия вузов. Нефть и Газ, 2009, 6, 4-9 [Belonosov A.Yu., Turenko S.K. Interpretation of satellite data of convective thermal flux in the prediction of hydrocarbon accumulations in the Kurgan region. Proceedings of Universities. Oil and gas, 2009, 6, 4-9 (in Russian)]

[7] Белоносов А.Ю. Поиск неантиклинальных залежей нефти и газа в Западной Сибири методом дистанционной и наземной геотерморазведки, Материаль II Международного геофизического конгресса Казахстана, Алма-Ата, 1998, 153-158 [Belonosov A.Yu. Searching nonanticlinal oil and gas fields in Western Siberia by remote and ground geological thermal exploration, Proceedings of the II International Geophysical Congress of Kazakhstan, Alma-Ata, 1998, 153-158 (in Russian)]

[8] Belonosov A.Yu. The distant heat investigations within the oil and gas areas of the Western Siberia, Proceedings of International conference "The earth's thermal field and related research methods", Moscow, 1998, 33-39.

[9] Belonosov A.Yu. Application of remote thermal surver for detection of hydrocarbon pools in West Siberia, Proceedings of IV International conference "The earth's thermal field and related research methods", Moscow, 2002, 17-25.

[10]Belonosov A.Yu. Ground Surface Verification of Satellite Prognosis of Promising Oil and Gas Fields, GORS XIV international Symposium on "Remote Sensing and Development”, Damascus, 2004, $55-58$.

[11]Белоносов А.Ю., Мартынов О.С., Шешуков С.А. Космические исследования конвективного теплового потока при прогнозировании залежей нефти и газа на юге Западной Сибири, Материалы Международной академической конференции «Состояние, тенденции и проблемы развития нефтегазового потенциала Западной Сибири», Тюмень, 2008, 61-65 [Bеlonosov A.Yu., Martynov O.S., Sheshukov S.A. Satellite research of convective heat flux in predicting oil and gas deposits in the south of Western Siberia, Proceedings of the International Academic Conference "State, trends and issues of oil and gas potential development in Western Siberia", Tyumen, 2008, 61-65 (in Russian)] 